\author{
MATERNAL EMPLOYMENT AND CHILDHOOD OBESITY: \\ A SEARCH FOR MECHANISMS IN TIME USE DATA \\ John Cawley \\ Feng Liu \\ Working Paper 13600 \\ http://www.nber.org/papers/w13600
}

\author{
NATIONAL BUREAU OF ECONOMIC RESEARCH \\ 1050 Massachusetts Avenue \\ Cambridge, MA 02138 \\ November 2007
}

The views expressed herein are those of the author(s) and do not necessarily reflect the views of the National Bureau of Economic Research.

(C) 2007 by John Cawley and Feng Liu. All rights reserved. Short sections of text, not to exceed two paragraphs, may be quoted without explicit permission provided that full credit, including $\odot$ notice, is given to the source. 
Maternal Employment and Childhood Obesity: A Search for Mechanisms in Time Use Data

John Cawley and Feng Liu

NBER Working Paper No. 13600

November 2007

JEL No. I12,J13,J22

\begin{abstract}
$\underline{\text { ABSTRACT }}$
Recent research has found that maternal employment is associated with an increased risk of childhood obesity. This paper explores mechanisms for that correlation. We estimate models of instrumental variables using a unique dataset, the American Time Use Survey, that measure the effect of maternal employment on the mother's allocation of time to activities related to child diet and physical activity. We find that employed women spend significantly less time cooking, eating with their children, and playing with their children, and are more likely to purchase prepared foods. We find suggestive evidence that these decreases in time are only partly offset by husbands and partners. These findings offer plausible mechanisms for the association of maternal employment with childhood obesity.
\end{abstract}

\title{
John Cawley
}

124 MVR Hall

Department of Policy Analysis and Management

Cornell University

Ithaca, NY 14853

and NBER

jhc38@cornell.edu

Feng Liu

Institute for Advanced Research

Shanghai University of Finance and Economics

Shanghai, China

f149@cornell.edu 


\section{Introduction and Context}

Over the past three decades the prevalence of overweight among American youth has risen dramatically. The Centers for Disease Control and Prevention (CDC) defines childhood overweight ${ }^{2}$ as a body mass index ${ }^{3}$ (BMI) above the 95 th percentile for children of the same age and gender (benchmarked against the historic BMI distribution). Since 1970, the fraction overweight has almost quadrupled among children aged 6-11 years and more than doubled among adolescents aged 12-19 years (Ogden et al., 2002).

The same period also witnessed a rise in female labor force participation. Between 1975 and 2005, the labor force participation rate of mothers with children under age 18 rose from 47 to 71 percent (U.S. Department of Labor, 2006).

A substantial recent literature has examined whether there is a relationship between these two trends; specifically, whether maternal employment raises the risk of childhood obesity (Anderson, Butcher, Levine 2003; Ruhm 2004; Classen and Hokayem 2005; Liu, Hsiao and Chou 2005; Fertig, Glomm and Tchernis 2006; Phipps, Lethbridge and Burton 2006; Chia 2006; Garcia, Labeaga, and Ortega 2006; Courtemanche 2007; Scholder 2007). A robust result in this literature is that children are indeed more likely to be overweight if their mother works. ${ }^{4}$ Rising maternal employment is estimated to

\footnotetext{
${ }^{2}$ The highest weight classification for adults is "obese" but in order to avoid stigmatizing youth with that label, the highest weight classification for children is "overweight." In this paper the terms are used interchangeably.

${ }^{3}$ Body mass index (BMI) is calculated as weight in kilograms divided by height in meters squared.

${ }^{4}$ Most of the studies on this question are of U.S. data and most of those examine data from the National Longitudinal Survey of Youth (NLSY) 1979 Cohort linked to the Children of the NLSY (Anderson, Butcher, Levine 2003; Ruhm 2004; Classen and Hokayem 2005; Liu, Hsiao and Chou 2005; Courtemanche 2007); one study examines U.S. data from the Panel Survey of Income Dynamics (PSID) Child Development Supplement linked to parental PSID data (Fertig, Glomm and Tchernis 2006). Others have examined data from Canada (Phipps, Lethbridge and Burton 2006; Chia 2006), Spain (Garcia, Labeaga,
} 
account for 7.7 percent of the overall increase in overweight children from 1968-2001

(Courtemanche 2007). There is no detectable correlation between paternal employment and childhood obesity (Phipps, Lethbridge and Burton 2006; Courtemanche 2007), which may be due to fathers shouldering less of the burden of cooking and child care (Hamermesh et al., 2005).

Many of these papers conclude with a call for research on the mechanisms by which maternal employment affects childhood obesity (e.g. Anderson, Butcher, and Levine 2003; Phipps et al. 2006; Garcia et al. 2006). This paper seeks to fill that void. The research questions of this paper are: What are the mechanisms by which maternal employment affects childhood obesity? How does maternal employment affect the mother's allocation of time to activities that are associated with child diet and physical activity? This study exploits a unique dataset that has not previously been examined in this context: the American Time Use Surveys for 2003-2006. It complements Fertig, Glomm and Tchernis (2006), which studies the relationship between maternal employment and the allocation of the child's time. ${ }^{5}$

The research questions of this paper are important for several reasons. First, it is important to understand what factors may have led to the recent rise in childhood obesity because it is a major public health concern with implications for physical health (Ebbeling, Pawlak, and Ludwig, 2002; Kimm and Obarzanek, 2002), mental health (Puhl and Brownell, 2002; Strauss, 2000), and medical care costs (Johnson, McInnes, and

and Ortega 2006), Japan (Takahashi et al. 1999) and the United Kingdom (Scholder 2007) and generally find results similar to those based on U.S. data.

${ }^{5}$ This paper also relates to a sociological literature on how time spent on household tasks like housework and child care are divided between spouses, and how the time allocation of women differs between those who do and do not work (e.g. Bianchi 2000; Nock and Kingston 1988). That literature is not focused on activities that may contribute to or prevent childhood obesity, and does not use IV or other methods to generate causal estimates of employment on the allocation of time. 
Shinogle, 2006; Wang and Dietz, 2002). Second, this study will shed light on possible unintended consequences of government policy to increase employment among women with children. For example, the 1996 Personal Responsibility and Work Opportunity Reconciliation Act (PRWORA) imposed work requirements for low-income single mothers to continue to receive cash assistance and set lifetime limits on receipt of federal cash assistance and thereby raised the labor force participation of low-income mothers (Blank, 2002). This paper will document how the employment of women with children results in changes in allocation of time that could have implications for the health of vulnerable children. Finally, it contributes more generally to the literature on parents' production of child health. A recent Journal of Health Economics article identified a need for more research on time inputs into the production of health (Leibowitz, 2004). This study partly fills that gap by taking advantage of unique new data on time use that "allow health economists to get a picture of time inputs into health production and their demographic and economic correlates” (Hamermesh et al., 2005, p. 231).

The outline of the paper is as follows. In the next section we briefly discuss our conceptual framework and describe our empirical methods. In section 3 we describe our data, the American Time Use Survey. Empirical results are provided in section 4 and section 5 offers a variety of extensions and sensitivity analyses. Section 6 puts the findings in context and offers conclusions.

\section{Conceptual Framework and Methods}

Our conception of how women make decisions about their allocation of time between employment and home production such as producing child health is based on the 
models of Becker (1976, 1991) and Grossman (2000) adapted to this context by Ruhm (2004). We do not reprint those models here but the basic intuition is that a mother allocates her time and budget to maximize her objective function, which includes, among other things, child outcomes. The fact that everyone faces a time constraint of 24 hours a day implies that all hours one spends working for pay are hours that cannot be devoted to other activities. While it is possible that working mothers rearrange their schedules so no less time is spent with children as a result of their employment, it is more likely that working leads to some reduction in women's time with their children. The goal of this study is not to naively test whether maternal employment results in any decrease in time with children, but to measure the amount of decrease in time spent in specific activities that relate to child diet and physical activity.

Specifically, we study the following activities that have been shown to be correlated with children's diet and physical activity. Time spent grocery shopping, cooking, and purchasing prepared foods are examined because when mothers enter the labor force the family may consume fewer meals prepared at home and more food prepared away from home. This is relevant for childhood obesity because, relative to food prepared at home, food prepared away from home has a greater density of fat and saturated fat and fewer nutrients (Lin et al., 1999). Less time spent cooking may also imply greater consumption of preserved packaged ready-to-eat foods, which Cutler et al. (2003) argue contributed to the rise in obesity.

We also examine the amount of time spent eating with children because eating meals as a family is associated with a higher-quality diet among children and adolescents; 
specifically: more fruits and vegetables, more nutrients, less saturated fat, and less soda pop (Neumark-Sztainer et al. 2003; Gillman et al. 2000).

We examine time spent playing with children and playing sports with children because those involve energy expenditure by children. Whether such activities prevent obesity depends on the counterfactual - what children would do if not playing with their parents or playing sports with parents. Although this undoubtedly varies by individual, on average children with working mothers spend significantly more time watching television (Fertig et al., 2006; Crepinsek and Burstein, 2004).

We also study the amount of time engaged in child care, supervising children, and the total time spent with children. These activities are relevant because children who are unsupervised or unattended (or those supervised or attended to by non-relatives) may be more sedentary or may snack more. Klesges et al. (1991) find that both the possibility of parental supervision and actual parental supervision markedly affect children's food selection, lowering the number of nonnutritious foods chosen and lowering the total caloric content of the meal.

We estimate two-part models (Jones, 2000; Cragg, 1971) of time devoted to specific activities, which is appropriate because a zero value of our dependent variable represents a genuine choice to spend zero minutes in that activity; i.e. it is not due to nonresponse. The first part of the model is a probit in which the dependent variable equals one if the respondent reports spending any time in that activity. The second part of the model is an ordinary least squares regression in which the dependent variable is the log of the number of minutes spent in that activity, conditional on spending some time. The regressor of interest is an indicator variable that equals one if the woman works for pay. 
(In the Extensions section, we show that our results are similar when we use weekly work hours instead of an indicator for employment.)

Identifying the causal effect of maternal employment is challenging because the mother's decision to work may be determined by unobserved factors that directly affect the outcomes of interest. For example, women with high levels of unobserved human capital may be more likely to work and may also (whether working or not) allocate their other time differently. Previous research has addressed the potential endogeneity of maternal employment several ways. Anderson, Butcher and Levine (2003) estimate IV models in which maternal employment is instrumented using state unemployment rate and state child care regulations, wages of child care workers, welfare benefit levels, and welfare regulations. Ruhm (2004) tested for the influence of unobserved factors by adding to his regression model a measure of future maternal employment, hypothesizing that if future maternal employment was significantly correlated with child weight after already controlling for current maternal employment then unobserved factors such as mother's taste for employment may bias estimates from simple models. This check was also subsequently conducted by Chia (2006) and Scholder (2007). Individual fixed effects models (Anderson, Butcher and Levine 2003; Scholder 2007) and sibling fixed effect models (Anderson, Butcher and Levine 2003; Chia 2006) have also been employed. In general, these studies fail to reject the hypothesis that maternal employment is exogenous in this context, implying little if any bias due to omitted variables.

We follow Anderson, Butcher and Levine (2003) and estimate IV models in which maternal employment is instrumented using state unemployment rate (controlling 
for year fixed effects). In the first stage regression, in which standard errors are clustered at the state level, the F statistic of the instrument is 16.6, which exceeds the generallyaccepted minimum standard of F=10 (Stock, Wright, and Yogo 2002).

Each of our regression models includes the following regressors: number of children in the household, age of youngest child, and indicator variables for mother's age category, education category, race and ethnicity, marital status, and whether the spouse (if any) is working full-time. Models also include indicator variables for day of the week, because maternal employment will affect the allocation of time differently by day depending on the work schedule, and for whether the day in question is a holiday. Models also include year fixed effects. We do not control for income because we wish to measure the full effect of maternal employment, part of which may work through income. In all regressions, the ATUS sampling weights are used and standard errors are clustered at individual level.

We do not estimate models of how paternal employment affects paternal time for two reasons. First, previous literature has found no detectable relationship between paternal employment and childhood obesity (Phipps, Lethbridge and Burton 2006; Courtemanche 2007). Second, our instrument of state monthly unemployment rate is not sufficiently predictive of paternal employment; i.e. the instrument does not pass the generally-accepted threshold for power in IV models (Stock, Wright, and Yogo 2002).

\section{Data: The American Time Use Survey (ATUS)}

The American Time Use Survey (ATUS) was first conducted in 2003 and has the goal of producing comprehensive information about how Americans spend their time. 
The ATUS sample is drawn from the outgoing rotation groups of the Current Population Survey. One individual from each selected household is chosen to participate in the ATUS. In a computer-assisted telephone interview, the respondent is interviewed once about his or her time use in a single 24-hour period (specifically, from 4 am to 4 am, ending on the interview day). The respondent describes every activity they undertook, how much time was spent, and with whom (for example, did housework for 30 minutes and my children were with me). The survey does not record secondary activities. For example, a person might have primarily driven to work but secondarily eaten breakfast while driving; the ATUS will code that time as spent driving but not record that they were also eating. Even though secondary activities are not recorded, it is possible to calculate total time spent with children because respondents do list who was with them during each activity. The ATUS organizes the data so that researchers can account for every minute of the respondent's day. Sample weights are provided to facilitate generalizations to the U.S. population. For more detail on the ATUS and its methods, see Hamermesh et al. (2005).

There are some limitations to the ATUS data. The response rate of the ATUS is under 60 percent in each year. Abraham et al. (2006) find that non-contact accounts for 60 percent of that non-response. They find little evidence that busy people are less likely to respond but considerable evidence that people who are weakly integrated into their communities (e.g. renters, urban residents) are less likely to be contacted and therefore participate. Another limitation specific to our research question is that the ATUS does not include measures of the body weight or diet of the respondents or their children. 
Despite its limitations, the ATUS has been praised for its usefulness for economic research (Herz and Devens, 2001; Hamermesh et al. 2005).

The ATUS was conducted annually 2003-2006; data from all of these years are pooled for this analysis. We include in our sample female respondents to the ATUS who have at least one child under the age of 18 in their household. Our final sample size is 15,287. Summary statistics are presented in Table 1. Among women in the sample, 66 percent are employed (whether part-time or full-time) and the average number of typical weekly work hours among the employed is 36 . The average number of children is 2 and the average age of youngest child is 7. Sixty-six percent of the ATUS sample of mothers is married, and 58 percent overall has a spouse working full time. Table 2 lists summary statistics for minutes spent on various activities for the sample as a whole as well as for non-working and working mothers. The unconditional means show that non-working mothers are more likely to spend any time grocery shopping, cooking, eating with children, playing with children, playing sports with children, child care, and supervising children. Interestingly, 19 percent of both employed and non-employed women with children in the household spent zero minutes with their children on the reference day. This could be for a variety of reasons, such as a long workday or the child was staying at a friend or relative's house that day. Less than one percent of mothers spend time playing sports with children, but those who do spend a lot of time in that activity: 56 minutes on average. Among women who spend any time in these activities, the average number of minutes spent is consistently greater for non-working than for working mothers. 


\section{Empirical Results}

Table 3 presents the results of two-part models of time allocated to specific activities. The cells of the table list the marginal effect of maternal employment (for the second part of the model, in which the dependent variable is the natural logarithm of the number of minutes, marginal effects are expressed in linear minutes). The table lists marginal effects only for the indicator for maternal employment but the models also control for the covariates listed in Table 1; the complete model results are available upon request.

Table 3 indicates that in the two part model that uses probit and OLS (i.e. does not instrument for maternal employment), maternal employment is consistently associated with less time spent on activities associated with child diet and physical activity: grocery shopping, cooking, eating with children, playing with children, playing sports with children, child care, supervising children, and the total time spent with children. The exception is that maternal employment is associated with a higher probability that the mother reports spending time purchasing prepared food. The magnitudes of the correlations are in some cases substantial. In the first stage, maternal employment is associated with a 5 percentage point lower probability of grocery shopping, 13 percentage point lower probability of doing any cooking, 10 percentage point lower probability of eating with the children, a 5 percentage point lower probability of playing with children, 8 percentage point lower probability that the mother engages in child care, a 3 percentage point lower probability of supervising children and a 4 percentage point lower probability that the mother spends any time with her children. Conditional on spending some time in these activities, working is associated with 8 fewer minutes 
grocery shopping, 12 fewer minutes cooking, 8 fewer minutes eating with the children, 18 fewer minutes playing with children, 11 fewer minutes playing sports with children, 26 fewer minutes engaged in child care, 8 fewer minutes supervising children and 139 fewer minutes spent with the children overall.

We also estimate IV versions of the two part models in order to address the endogeneity of maternal employment. This results in a large increase in standard errors. The results of Hausman tests indicate that we cannot reject the null hypothesis that employment status is exogenous; in other words, the benefits of IV are not worth their costs and the non-IV versions of the model are preferred. This failure to reject the exogeneity of maternal employment in this context is consistent with several previous studies of maternal employment and childhood obesity (e.g. Anderson, Butcher and Levine 2003, Chia 2006; Scholder 2007).

\section{Extensions and Sensitivity Analyses}

We conduct four extensions to our basic model: 1) re-estimate the model using hours worked instead of an indicator for maternal employment as the regressor of interest; 2) test for differences across socioeconomic status; 3) examine whether results differ for single mothers versus those with a spouse or unmarried partner present; and 4) examine whether fathers whose wives work spend more time on these activities.

Previous research on the association between maternal employment and childhood obesity has frequently examined the impact of work hours (Anderson, Butcher and Levine 2003; Ruhm 2004; Classen and Hokayem 2005; Fertig, Glomm and Tchernis 
2006; Chia 2006; Phipps, Lethbridge and Burton 2006; Courtemanche 2007). ${ }^{6}$ For this reason, we re-estimate our models using hours worked instead of an indicator for maternal employment as the regressor of interest. Results are provided in Table 4. The hours worked variable is expressed in individual hours, the mean of which is 36 . On the whole, the pattern of results for hours worked (Table 4) is similar to those for an indicator for employment (Table 3). In Table 4, the basic (non-IV) model implies that a higher number of typical hours worked per week is associated with a lower probability of spending any time grocery shopping, cooking, eating with children, playing with children, playing sports with children, child care, supervising children, and any time with children overall. In most cases there are also significant differences on the intensive margin. On the whole, the magnitudes are similar to those in Table 3; for example, in the basic (non-IV) version of the second part of the model for total time spent with children, an additional hour worked per week is associated with 3.5 fewer minutes spent with children among mothers who spend any time with children. The mean number of weekly hours worked is 36 , and so moving from zero hours worked to mean hours worked is associated with 3.5 times 36, or 126 fewer minutes spent with children, which is similar to the estimate in Table 3 that moving from not employed to employed is associated with 139 fewer minutes spent with children overall. The F-statistic of the instrument, state monthly unemployment rate, in the first stage of the IV model is 12.5, which again passes the minimum threshold for power (Stock, Wright, and Yogo 2002). ${ }^{7}$ Hausman tests again indicate that we cannot reject the null hypothesis that work hours are exogenous in this

\footnotetext{
${ }^{6}$ In contrast, Scholder (2007) uses indicator variables for part-time and full-time employment at different ages of the child.

${ }^{7}$ As before, the first stage includes indicator variables for year, and the standard errors are clustered by state.
} 
context, which is what previous studies that examined maternal hours worked also found (e.g. Anderson, Butcher and Levine 2003). For this reason the basic (non-IV) model is preferred to the IV model. On the whole, the estimates of models that use number of work hours are very similar to those of models that use an indicator for maternal employment.

Previous research has found that the correlation between maternal employment and child obesity is strongest in families of high socioeconomic status (Anderson, Butcher and Levine 2003; Ruhm 2004; Fertig, Glomm and Tchernis 2006). For this reason, we estimate our initial models (i.e. those that use an indicator variable for maternal employment) separately by socioeconomic status, defined three ways: maternal education (as in Anderson, Butcher and Levine 2003; Ruhm 2004; and Fertig, Glomm and Tchernis 2006), family income (as in Anderson, Butcher and Levine 2003; Ruhm 2004), and race/ethnicity (as in Anderson, Butcher and Levine 2003; Ruhm 2004). We find no significant differences or consistent pattern of coefficient point estimates across maternal education (high school graduate or less versus some college or more), family income (below versus above $\$ 50,000$ ) or race/ethnicity (African-American or Hispanic versus white); the full results are available upon request.

Some of the decreases in time by the mother may be offset by increases in time by the father; in general, time allocation decisions may be made jointly to maximize the household's objective function (Becker 1976, 1991). The ATUS includes only one adult per household so we are unable to test conclusively for such adjustments within couples, but we are able to conduct two tests that shed some light on this possibility. First, we examine whether the changes in activity time associated with employment are greater for 
women who have a husband or partner present in the household than for single mothers. We find some evidence that women who have a husband or partner in the household reduce time to a greater extent than single mothers. Specifically, we find that maternal employment has a smaller (in absolute value) impact on the following for single mothers than for mothers with a spouse or partner: whether spend any time eating with children, whether spend any time on child care, and whether spend any time with children. For these activities, the results are consistent with husbands or partners taking on more of these tasks when women work, making a greater decrease optimal for mothers with spouses or partners. We fail to reject the null hypothesis of equality for all other activities (full results are available upon request).

We also examine whether men in the ATUS with a working wife report more time spent in these activities than men whose wife does not work (controlling for the man's employment). Results are presented in Table 5. We find that, among ATUS men with children, those whose wife is employed are 11 percentage points more likely to cook, 10 percentage points more likely to engage in some child care, 1 percentage point more likely to supervise children and 3 percentage points more likely to spend some time with their children. On the intensive margin, men with a working spouse spend roughly 4 more minutes cooking, 8 more minutes playing with children, and 13 more minutes with children overall each day. This too suggests that husbands and partners take up some of the slack created by maternal employment, but the magnitude of the increase by fathers is much less than the decrease by mothers so on net less time is spent on these activities. For example, working is associated with mothers spending 139 fewer minutes with children overall (among those who spend any), but having a wife who is employed is 
associated with fathers spending only 13 more minutes with children overall (again, among those who spend any). Moreover, the evidence is mixed whether fathers provide additional meals cooked from scratch. While they do spend more time cooking, they also spend 4 fewer minutes grocery shopping and are 2 percentage points more likely to purchase prepared foods.

\section{Discussion}

A recent Journal of Health Economics essay urged more research on time inputs into the production of health (Leibowitz, 2004). This paper is one such study, measuring how maternal employment affects the allocation of time to activities related to child diet and physical activity, using data uniquely well suited to answer such questions (Hamermesh et al., 2005).

Exploring time use data for 2003-2006, we find plausible mechanisms for the correlation of maternal employment with childhood obesity. We find that maternal employment is associated with a lower probability of, and reductions in time spent, grocery shopping and cooking, and a higher probability of purchasing prepared foods. Moreover, we find that when wives work husbands spend significantly less time grocery shopping and are more likely to purchase prepared foods. Our results are consistent with those of Crepinsek and Burstein (2004), who find that children of working mothers consume a greater share of meals and snacks from away-from-home sources. Awayfrom-home foods have been linked to a higher risk of childhood obesity (IOM, 2005) because they have a higher fat density and lower nutrient density than foods prepared at home (Lin et al., 1999). Increased consumption of another substitute for home cooked 
meals - prepackaged ready-to-eat foods - may also have contributed to the rise in obesity (Cutler et al., 2003).

We also find that working mothers are less likely to eat with their children. This is relevant for childhood obesity because eating meals as a family is associated with children consuming a less fatty and more nutritious diet (Neumark-Sztainer et al. 2003; Gillman et al. 2000).

Our finding that working mothers spend less time playing with their children and playing sports with their children is consistent with earlier findings that children of working mothers spend more hours watching TV (Fertig, Glomm, and Tchernis 2006; Chia 2006; Crepinsek and Burstein, 2004). All else equal, less physically active children are at greater risk of obesity (IOM, 2005).

Finally, we find that employment is associated with mothers spending less time engaged in child care, supervising children, and less time overall spent with children. This is relevant for childhood obesity because there is evidence that unsupervised children consume more calories (Klesges et al. 1991).

This study has limitations. Although the results of the Hausman test suggest that the OLS estimates are preferred to the IV estimates, it is appropriate to discuss what is being measured in the IV models. Ideally we would estimate the average treatment effect (ATE) of maternal employment for all women with children, but our IV estimates reflect only the impact of maternal employment for women whose labor force participation is affected by state unemployment rate. These women may differ from the average woman; for example, they may be less attached to the labor force or less educated. If so, our IV results measure a Local Average Treatment Effect (LATE) rather than the ATE and 
caution should be used when generalizing to the entire population of women (Imbens and Angrist, 1994). Another possible aspect in which the LATE may differ from the ATE is that our variation in maternal employment may be due to involuntary unemployment caused by macroeconomic fluctuations, and sudden or involuntary unemployment may result in disequilibrium in time allocation. Still, this LATE is of interest; Hamermesh et al. (2005) note that the ATUS is promising to study "how shocks ... result in substitution between market and nonmarket work...how different types of household production activities vary over the business cycle” (p. 228). In addition, the most prominent paper in this literature (Anderson, Butcher, and Levine, 2003) used the same instrument (plus others relating to welfare policies and day care costs), implying that the results of the two papers are comparable.

Maternal employment involves a tradeoff: less time in the household in exchange for more income. We acknowledge that the additional earned income yields benefits for the household, benefits that are not measured or discussed in this paper. To clarify, our intent is not to calculate the net benefits of maternal employment, but to identify possible mechanisms that explain the observed correlation between maternal employment and childhood obesity.

The ATUS records primary, but not secondary, activities, so if employment causes mothers to switch some child-centered activities from primary to secondary in nature, then the models of this paper overstate the reductions in time due to employment. We are unable to examine joint parental decisionmaking because the ATUS includes only one adult per household. We find that husbands and partners with working spouses spend more time on certain of these activities, but this offsets only a small percentage of 
the decrease associated with maternal employment. Finally, the composition of the diet and the children's body weights are not recorded by the ATUS. Despite these limitations, this study contributes to the recent literature on maternal employment and childhood overweight by demonstrating several plausible mechanisms for the association.

It is unlikely that the trend toward female labor market participation will reverse (and we do not take the position that it should), so the results of this paper have implications for public health policy. Specifically, given that families may continue to rely to a greater extent on food prepared away from home, the U.S. could consider nutrition policies to improve consumers' information about the calorie and fat content of away-from-home foods (IOM 2005; Lin et al., 1999). Also, given the external health care costs associated with obesity (Finkelstein, Fiebelkorn and Wang 2003), policymakers may wish to facilitate physical activity in schools to offset any decrease that occurs at home due to a decrease in supervision (IOM, 2005). 


\section{Works Cited}

Abraham, Katharine G., Aaron Maitland, Suzanne M. Bianchi. 2006. "Non-response in the American Time Use Survey: Who Is Missing from the Data and How Much Does It Matter?” NBER Technical Working Paper No. 328.

Anderson, Patricia M., Kristin F. Butcher and Phillip B. Levine. 2003. "Maternal Employment and Overweight Children.” Journal of Health Economics, 22: 477-504.

Becker, Gary S. 1976. An Economic Approach to Human Behavior. (Chicago IL: University of Chicago Press).

Becker, Gary S. 1991. A Treatise on the Family, Enlarged Edition. (Cambridge MA: Harvard University Press).

Bianchi, Suzanne M. 2000. "Maternal Employment and Time with Children: Dramatic Change or Surprising Continuity?” Demography 37(4): 401-414.

Blank, R. M. 2002. "Evaluating Welfare Reform in the United States." Journal of Economic Literature, XL(4), 1105-1166.

Chia, Yee Fei. 2006. "Maternal Labour Supply and Childhood Overweight and Obesity in Canada: Evidence From the NLSCY.” Working Paper, University of Toronto.

Classen, Timothy and Charles Hokayem. 2005. "Childhood Influences on Youth Obesity.” Economics and Human Biology, 3:165-87.

Courtemanche, Charles. "Working Yourself to Death? The Relationship Between Work Hours and Obesity.” Working paper, Washington University of St. Louis.

Cragg, J.G. 1971. "Some Statistical Models for Limited Dependent Variables with Application to the Demand for Durable Goods.” Econometrica, 39(5): 829-844.

Crepinsek, Mary Kay, and Nancy R. Burstein. 2004. Maternal Employment and Children's Nutrition: Volume II: Other Nutrition-Related Outcomes. Washington DC: Economic Research Service, U.S. Department of Agriculture. E-FAN-04006-2.

Cutler, David M., Edward L. Glaeser and Jesse M. Shapiro. 2003. "Why Have Americans Become More Obese?” Journal of Economic Perspectives 17(3): 93118.

Ebbeling, Cara B., Dorota B. Pawlak, and David S. Ludwig. 2002. "Childhood Obesity: Public Health Crisis, Common Sense Cure." Lancet, 360: 473-482.

Fertig, Angela, Gerhard Glomm and Rusty Tchernis. 2006. "The Connection Between Maternal Employment and Childhood Obesity: Inspecting the Mechanisms.” Center for Applied Economics and Policy Research Working Paper \#2006-020.

Finkelstein E, I. Fiebelkorn and G. Wang. 2003. "National medical spending attributable to overweight and obesity: How much and who’s paying?” Health Affairs Web Exclusive, 14 May.

Garcia, Emma, Jose M. Labeaga, and Carolina Ortega. 2006. “Maternal Employment and Childhood Obesity in Spain.” Working paper, FEDEA, Madrid, Spain.

Gillman, Matthew W., Sheryl L. Rifas-Shiman; A. Lindsay Frazier; Helaine R. H. Rockett; Carlos A. Camargo Jr; Alison E. Field; Catherine S. Berkey; Graham A. Colditz. 2000. "Family Dinner and Diet Quality Among Older Children and Adolescents.” Archives of Family Medicine, 9:235-240. 
Grossman, Michael. 2000. “The Human Capital Model.” In: A.J. Culyer and J. P. Newhouse (eds.), Handbook of Health Economics, volume 1A (New York: Elsevier).

Hamermesh, Daniel S., Harley Frazis, and Jay Stewart. 2005. "Data Watch: The American Time Use Survey.” Journal of Economic Perspectives, 19(1): 221-232.

Herz, Diane and Richard M. Devens, Jr. 2001. "The American Time-Use Survey.” Industrial Relations, 40(3): 526-529.

Imbens, G.W., and J.D. Angrist. 1994. "Identification and Estimation of Local Average Treatment Effects.” Econometrica, 62: 467-476.

Institute of Medicine. 2005. Preventing Childhood Obesity: Health in the Balance. National Academies Press: Washington DC.

Johnson, Eric, Melayne Morgan McInnes, and Judith A. Shinogle. 2006. "What is the Economic Cost of Overweight Children?” Eastern Economic Journal, 32(1): 171-187.

Jones, Andrew M. 2000. “Health Econometrics” Chapter 6 in Anthony J. Culyer and Joseph P. Newhouse, editors, Handbook of Health Economics, Volume 1A, pp. 265-336.

Kimm, S.Y.S., and Obarzanek, E. 2002. "Childhood Obesity: A New Pandemic of the New Millennium." Pediatrics 110(5):1003-1007.

Klesges, Robert C., Risa J. Stein, Linda H. Eck, Terry R. Isbell, and Lisa M. Klesges. 1991. "Parental Influence on Food Selection in Young Children and its Relationships to Childhood Obesity.” American Journal of Clinical Nutrition, 53(4): 859-64.

Lamerz, A., J. Kuepper-Nybelen, C Wehle, et al. 2005. "Social Class, Parental Education, and Obesity Prevalence in a Study of Six-Year-Old Children in Germany.” International Journal of Obesity, 29: 373-380.

Leibowitz, AA. 2004. "The Demand for Health and Health Concerns after 30 Years." Journal of Health Economics, 23(4): 663-671.

Lin, Biing-Hwan, Joanne Guthrie, and Elizabeth Frazao. 1999. Away-From-Home Foods Increasingly Important to Quality of American Diet. Washington DC: U.S. Department of Agriculture, Economic Research Service. AIB-749.

Liu, Echu, Cheng Hsiao, and Shin-Yi Chou. 2005. "Maternal Full-Time Employment and Childhood Obesity: Parametric and Semiparametric Estimation.” Working paper, University of Southern California.

Neumark-Sztainer, Dianne, Peter J Hannan, Mary Story, Jillian Croll, Cheryl Perry. 2003. "Family meal patterns: Associations with sociodemographic characteristics and improved dietary intake among adolescents." Journal of the American Dietetic Association, 103(3): 317-322.

Nock, Steven L. and Paul William Kingston. 1988. "Time with children: The impacts of couples' work-time commitments.” Social Forces, 67(1): 59-85.

Ogden, Cynthia L., Katherine M. Flegal, Margaret D. Carroll, and Clifford L. Johnson. 2002. "Prevalence and Trends in Overweight Among US Children and Adolescents, 1999-2000." Journal of the American Medical Association, 288(14): 1728-1732. 
Phipps SA, Lethbridge L, Burton P. 2006. "Long-run consequences of parental paid work hours for child overweight status in Canada.” Social Science \& Medicine, 62(4): 977-986.

Puhl, Rebecca, and Kelly D. Brownell. 2002. "Stigma, Discrimination, and Obesity." In C.G. Fairburn and K.D. Brownell (eds.), Eating Disorders and Obesity: A Comprehensive Handbook. Guilford Press: New York.

Ruhm, Christopher J. 2004. "Maternal Employment and Adolescent Development." National Bureau of Economic Research Working Paper \#10691.

Scholder, Stephanie von Hinke Kessler. 2007. "Maternal Employment and Overweight Children: Does Timing Matter?” Paper presented at the International Health Economics Association World Congress.

Stock, James H., Jonathan H. Wright, and Motohiro Yogo. 2002. “A Survey of Weak Instruments and Weak Identification in Generalized Method of Moments.” Journal of Business and Economic Statistics, 20(4): 518-529.

Strauss, Richard S. 2000. "Childhood Obesity and Self-Esteem." Pediatrics, 105(1): e15-e20.

Takahashi, Eiko, Katsumi Yoshida, Hiroki Sugimori, et al. 1999. "Influence Factors on the Development of Obesity in 3-Year-Old Children Based on the Toyama Study.” Preventive Medicine, 28:293-296.

U.S. Department of Labor. 2006. Women in the Labor Force: A Databook. Washington DC: U.S. Department of Labor

Wang, Guijing, and W.H. Dietz. 2002. "Economic Burden of Obesity in Youths Aged 6 to 17 Years: 1979-1999.” Pediatrics, 109(5): 81-86. 
Table 1: Summary Statistics

American Time Use Surveys, 2003-2006

$\mathrm{N}=15,287$

\begin{tabular}{|c|c|}
\hline Variable & Percent of Sample or Mean Value \\
\hline Respondent employed & $65.87 \%$ \\
\hline $\begin{array}{l}\text { Total hours usually worked per week (if } \\
\text { employed) }\end{array}$ & 35.96 \\
\hline \multicolumn{2}{|l|}{ Age } \\
\hline$-18-24$ & $14.52 \%$ \\
\hline$-25-34$ & $29.61 \%$ \\
\hline$-35-44$ & $35.27 \%$ \\
\hline$-45-54$ & $15.73 \%$ \\
\hline$-55+$ & $4.87 \%$ \\
\hline \multicolumn{2}{|l|}{ Education } \\
\hline - less than high school & $15.31 \%$ \\
\hline - high school & $30.17 \%$ \\
\hline - some college & $28.70 \%$ \\
\hline - college + & $25.82 \%$ \\
\hline \multicolumn{2}{|l|}{ Race } \\
\hline - white & $62.27 \%$ \\
\hline - black & $14.11 \%$ \\
\hline - Hispanic & $18.38 \%$ \\
\hline - other & $5.24 \%$ \\
\hline \multicolumn{2}{|l|}{ Marital status } \\
\hline - Married & $65.79 \%$ \\
\hline - Divorced, separated or widowed & $14.37 \%$ \\
\hline - Never married & $19.84 \%$ \\
\hline Age of youngest child $<18$ & 7 \\
\hline Number of children & 2 \\
\hline Spouse working full-time & $57.57 \%$ \\
\hline Holiday & $1.85 \%$ \\
\hline \multicolumn{2}{|l|}{ Weekday } \\
\hline - Sunday & $14.31 \%$ \\
\hline - Monday & $14.25 \%$ \\
\hline - Tuesday & $14.17 \%$ \\
\hline - Wednesday & $14.33 \%$ \\
\hline - Thursday & $13.87 \%$ \\
\hline - Friday & $14.82 \%$ \\
\hline - Saturday & $14.25 \%$ \\
\hline \multicolumn{2}{|l|}{ Year } \\
\hline-2003 & $24.71 \%$ \\
\hline-2004 & $24.92 \%$ \\
\hline-2005 & $25.14 \%$ \\
\hline-2006 & $25.23 \%$ \\
\hline
\end{tabular}


Notes:

1) Data: American Time Use Surveys, 2003-2006

2) Sample is restricted to women who have at least one child under the age of 18 years in their household.

3) For total hours usually worked per week only, the total sample size is 14,884 . For all other variables it is 15,287 . Nonresponse to the hours worked question explains the difference. 
Table 2

Women's Allocation of Time

\begin{tabular}{|c|c|c|c|c|c|c|}
\hline \multirow[b]{2}{*}{ Activity } & \multicolumn{2}{|c|}{ All women } & \multicolumn{2}{|c|}{ Non-working women } & \multicolumn{2}{|c|}{ Working women } \\
\hline & $\begin{array}{c}\text { Percent } \\
\text { Reporting any } \\
\text { Time on this } \\
\text { Activity }\end{array}$ & $\begin{array}{c}\text { \# Minutes } \\
\text { Spent on } \\
\text { Activity if }>0\end{array}$ & $\begin{array}{c}\text { Percent } \\
\text { Reporting any } \\
\text { Time on this } \\
\text { Activity }\end{array}$ & $\begin{array}{c}\text { \# Minutes } \\
\text { Spent on } \\
\text { Activity if }>0\end{array}$ & $\begin{array}{c}\text { Percent } \\
\text { Reporting any } \\
\text { Time on this } \\
\text { Activity }\end{array}$ & $\begin{array}{c}\text { \# Minutes Spent on } \\
\text { Activity if }>0\end{array}$ \\
\hline Grocery shopping & $20.69 \%$ & 47.49 & $23.27 \%$ & 53.59 & $19.36 \%$ & 43.70 \\
\hline Cooking & $69.44 \%$ & 58.86 & $78.23 \%$ & 70.77 & $64.89 \%$ & 51.42 \\
\hline $\begin{array}{l}\text { Purchasing prepared } \\
\text { food }\end{array}$ & $13.69 \%$ & 10.55 & $10.40 \%$ & 11.46 & $15.40 \%$ & 10.23 \\
\hline Eating with children & $66.49 \%$ & 51.96 & $71.96 \%$ & 57.50 & $63.66 \%$ & 48.72 \\
\hline Playing with children & $16.58 \%$ & 100.61 & $22.52 \%$ & 110.97 & $13.51 \%$ & 91.65 \\
\hline $\begin{array}{l}\text { Playing sports with } \\
\text { children }\end{array}$ & $0.83 \%$ & 55.97 & $1.05 \%$ & 63.48 & $0.71 \%$ & 50.20 \\
\hline Child care & $68.75 \%$ & 116.12 & $73.00 \%$ & 146.89 & $66.54 \%$ & 98.63 \\
\hline Supervising child & $7.89 \%$ & 66.72 & $10.70 \%$ & 77.03 & $6.44 \%$ & 57.84 \\
\hline $\begin{array}{l}\text { Total time spent with } \\
\text { children }\end{array}$ & $80.64 \%$ & 401.83 & $80.71 \%$ & 513.94 & $80.60 \%$ & 343.66 \\
\hline Sample size & \multicolumn{2}{|c|}{15,287} & \multicolumn{2}{|c|}{4,880} & \multicolumn{2}{|c|}{10,407} \\
\hline
\end{tabular}

Data: American Time Use Surveys, 2003-2006, women with at least one child in the household under the age of 18. 
Table 3

Maternal Employment and Allocation of Time to Activities Associated with Child Diet and Physical Activity

\begin{tabular}{|l|c|c|c|c|}
\hline \multirow{2}{*}{ Activity } & \multicolumn{2}{c|}{$\begin{array}{c}\text { Part One: } \\
\text { Whether report any time } \\
\text { spent on this activity }\end{array}$} & \multicolumn{2}{c|}{$\begin{array}{c}\text { Part Two: } \\
\text { Number of minutes spent on } \\
\text { activity if }>\text { 0 }\end{array}$} \\
\cline { 2 - 5 } & Probit & Probit IV & OLS & 2SLS \\
\hline Grocery shopping & $-0.05^{* * *}$ & -0.28 & $-7.67 * * *$ & 33.25 \\
& $(-5.12)$ & $(-1.54)$ & $(-5.44)$ & $(0.38)$ \\
\hline Cooking & $-0.13^{* * *}$ & 0.06 & $-11.97 * * *$ & -25.62 \\
& $(-11.91)$ & $(0.30)$ & $(-11.80)$ & $(-1.25)$ \\
\hline Purchasing & $0.03^{* * *}$ & -0.08 & -0.32 & 8.04 \\
prepared food & $(4.29)$ & $(-0.53)$ & $(-0.73)$ & $(0.57)$ \\
\hline Eating with & $-0.10^{* * *}$ & -0.21 & $-8.16 * *$ & $-47.07 * *$ \\
children & $(-8.33)$ & $(-1.04)$ & $(-9.64)$ & $(-2.16)$ \\
\hline Playing with & $-0.05 * * *$ & 0.04 & $-18.07 * * *$ & -17.61 \\
children & $(-8.42)$ & $(0.27)$ & $(-6.01)$ & $(-0.22)$ \\
\hline Playing sports & $-0.002^{*}$ & 0.03 & $-11.24 *$ & -169.29 \\
with children & $(-1.71)$ & $(0.91)$ & $(-1.68)$ & $(-0.98)$ \\
\hline Child care & $-0.08^{* * *}$ & 0.06 & $-25.88^{* * *}$ & -60.07 \\
& $(-6.54)$ & $(0.31)$ & $(-12.21)$ & $(-0.94)$ \\
\hline Supervising child & $-0.03^{* * *}$ & 0.17 & $-8.48^{* * *}$ & -138.34 \\
& $(-5.32)$ & $(1.45)$ & $(-2.72)$ & $(-1.57)$ \\
\hline Total time spent & $-0.04 * * *$ & -0.08 & $-139.06 * * *$ & -184.26 \\
with children & $(-4.71)$ & $(-0.45)$ & $(-20.81)$ & $(-1.13)$ \\
\hline
\end{tabular}

Notes:

1) Data: American Time Use Surveys, 2003-2006. Sample size: 15,287.

2) Cells list marginal effects associated with maternal employment, with t-statistics are in parentheses. Statistical significance (based on a two-tailed test) is indicated with asterisks: $* * * \mathrm{P}<0.01, * * \mathrm{P}<0.05, * \mathrm{P}<0.1$.

3) Table reports marginal effects only for indicator variable for employment (=1 if employed, 0 if unemployed). Models also control for all variables listed in Table 1 ; complete model results are available upon request.

4) In all regressions, sampling weights are applied and standard errors are clustered at individual level.

5) The dependent variable in time spent model is log minutes. Marginal effects are transformed back to minutes.

6) In the IV model, the instrumental variable is state monthly unemployment rate. In the first-stage regression (with standard errors are clustered at state level) the $\mathrm{F}$ statistic of the instrument is $\mathbf{1 6 . 5 8 \text { . }}$ 
Table 4

Maternal Work Hours and Allocation of Time to Activities Associated with Child Diet and Physical Activity

\begin{tabular}{|c|c|c|c|c|}
\hline \multirow[t]{2}{*}{ Activity } & \multicolumn{2}{|c|}{$\begin{array}{c}\text { Part One: } \\
\text { Whether report any time } \\
\text { spent on this activity }\end{array}$} & \multicolumn{2}{|c|}{$\begin{array}{c}\text { Part Two: } \\
\text { Number of minutes spent on } \\
\text { activity if }>0\end{array}$} \\
\hline & Probit & Probit IV & OLS & 2SLS \\
\hline Grocery shopping & $\begin{array}{c}-0.002 * * * \\
(-7.83)\end{array}$ & $\begin{array}{l}-0.007 \\
(-1.36)\end{array}$ & $\begin{array}{c}-0.155^{* * *} \\
(-4.48)\end{array}$ & $\begin{array}{l}0.497 \\
(0.26)\end{array}$ \\
\hline Cooking & $\begin{array}{c}-0.003 * * * \\
(-12.64)\end{array}$ & $\begin{array}{l}0.003 \\
(0.47)\end{array}$ & $\begin{array}{c}-0.310 * * * \\
(-12.86)\end{array}$ & $\begin{array}{l}-0.533 \\
(-1.08)\end{array}$ \\
\hline $\begin{array}{l}\text { Purchasing } \\
\text { prepared food }\end{array}$ & $\begin{array}{l}0.001 * * * \\
(3.99)\end{array}$ & $\begin{array}{l}-0.002 \\
(-0.44)\end{array}$ & $\begin{array}{l}-0.007 \\
(-0.73)\end{array}$ & $\begin{array}{l}0.188 \\
(0.42)\end{array}$ \\
\hline $\begin{array}{l}\text { Eating with } \\
\text { children }\end{array}$ & $\begin{array}{c}-0.003 * * * \\
(-8.85)\end{array}$ & $\begin{array}{l}-0.006 \\
(-1.02)\end{array}$ & $\begin{array}{l}-0.208 * * \\
(-10.23)\end{array}$ & $\begin{array}{c}-1.118^{* *} \\
(-1.96)\end{array}$ \\
\hline $\begin{array}{l}\text { Playing with } \\
\text { children }\end{array}$ & $\begin{array}{c}-0.001 * * * \\
(-9.28)\end{array}$ & $\begin{array}{l}0.000 \\
(0.09)\end{array}$ & $\begin{array}{c}-0.546 * * * \\
(-7.25)\end{array}$ & $\begin{array}{l}-0.626 \\
(-0.30)\end{array}$ \\
\hline $\begin{array}{l}\text { Playing sports } \\
\text { with children }\end{array}$ & $\begin{array}{c}-0.0001^{*} \\
(-1.65)\end{array}$ & $\begin{array}{l}0.000 \\
(0.42)\end{array}$ & $\begin{array}{l}-0.187 \\
(-1.06)\end{array}$ & $\begin{array}{c}-48.208 \\
(-0.12)\end{array}$ \\
\hline Child care & $\begin{array}{c}-0.002 * * * \\
(-8.10)\end{array}$ & $\begin{array}{l}0.001 \\
(0.10)\end{array}$ & $\begin{array}{c}-0.668 * * * \\
(-13.41)\end{array}$ & $\begin{array}{l}-1.356 \\
(-0.78)\end{array}$ \\
\hline Supervising child & $\begin{array}{c}-0.001 * * * \\
(-6.32)\end{array}$ & $\begin{array}{l}0.004 \\
(1.37)\end{array}$ & $\begin{array}{c}-0.219 * * * \\
(-2.81)\end{array}$ & $\begin{array}{l}-3.238 \\
(-1.46)\end{array}$ \\
\hline $\begin{array}{l}\text { Total time spent } \\
\text { with children }\end{array}$ & $\begin{array}{c}-0.001 * * * \\
(-4.42)\end{array}$ & $\begin{array}{l}-0.002 \\
(-0.43)\end{array}$ & $\begin{array}{c}-3.488 * * * \\
(-21.16)\end{array}$ & $\begin{array}{l}-3.546 \\
(-0.93)\end{array}$ \\
\hline
\end{tabular}

Notes:

1) Data: American Time Use Surveys, 2003-2006. Sample size: 14,884.

2) Cells list marginal effects associated with maternal working hours, with tstatistics are in parentheses. Statistical significance (based on a two-tailed test) is indicated with asterisks: $* * * \mathrm{P}<0.01, * * \mathrm{P}<0.05$, * $\mathrm{P}<0.1$.

3) Table reports marginal effects only for usual working hours per week ( 0 if not working). Models also control for all variables listed in Table 1; complete model results are available upon request.

4) In all regressions, sampling weights are applied and standard errors are clustered at individual level.

5) The dependent variable in time spent model is log minutes. Marginal effects are transformed back to minutes.

6) In the IV model, the instrumental variable is state monthly unemployment rate. In the first-stage regression (with standard errors are clustered at state level) the $\mathrm{F}$ statistic of the instrument is 12.47 . 
Table 5

Maternal Employment and Father's Time Spent on Activities Associated with Child Diet and Physical Activity

\begin{tabular}{|l|c|c|}
\hline \multirow{1}{*}{ Activity } & $\begin{array}{c}\text { Part One: } \\
\text { Whether report } \\
\text { any time spent on } \\
\text { this activity }\end{array}$ & $\begin{array}{c}\text { Part Two: } \\
\text { Number of minutes } \\
\text { spent on activity } \\
\text { if }>\mathbf{0}\end{array}$ \\
\cline { 2 - 3 } & Probit & OLS \\
\hline Grocery shopping & 0.01 & $-3.93^{*}$ \\
& $(0.84)$ & $(-1.72)$ \\
\hline Cooking & $0.11^{* * *}$ & $3.98^{* * *}$ \\
& $(7.93)$ & $(2.83)$ \\
\hline Purchasing prepared food & $0.02^{* *}$ & -0.26 \\
& $(2.40)$ & $(-0.59)$ \\
\hline Eating with children & 0.01 & -1.25 \\
& $(0.90)$ & $7.53^{*}$ \\
\hline Playing with children & 0.00 & $(1.91)$ \\
\hline Playing sports with & $(0.56)$ & 0.38 \\
children & 0.00 & $(0.04)$ \\
\hline Child care & $(0.40)$ & 2.34 \\
& $0.10^{* * *}$ & $(0.94)$ \\
\hline Supervising child & $(-6.47)$ & 4.95 \\
& $0.01^{* * *}$ & $(0.63)$ \\
\hline Total time spent with & $(2.64)$ & $13.31^{* *}$ \\
children & $0.03^{* *}$ & $(1.98)$ \\
\hline
\end{tabular}

Notes:

1) Data: American Time Use Surveys, 2003-2006. The sample is restricted to men with spouse or unmarried partner present and at least one child in the household under the age of 18 . The sample size is 9,116 .

2) Cells list marginal effects associated with spouse's employment, with t-statistics are in parentheses. Statistical significance (based on a two-tailed test) is indicated with asterisks: *** $\mathrm{P}<0.01$, ** $\mathrm{P}<0.05$, * $\mathrm{P}<0.1$.

3) Table reports marginal effects only for indicator variable for spousal employment (=1 if employed, 0 if not). Models also control for paternal employment and all variables listed in Table 1; complete model results are available upon request.

4) In all regressions, sampling weights are applied and standard errors are clustered at individual level.

5) The dependent variable in time spent model is log minutes. Marginal effects are transformed back to minutes. 